\title{
Identification of Athletic Human Growth Hormone Gene Polymorphisms
}

\author{
Mohammed H Awwad* and Hany A. Eldeeb** \\ * Department of Zoology, Faculty of Science, Benha University. \\ ** Department of Training sports, Faculty of Physical Education, Monofia University.
}

\begin{abstract}
Background: PCR/RFLP of Human growth hormone gene was used to differentiate among ten athletes.

Results: AatI, AviII, BsaI, HindII, and SacI restriction endonucleases gave high levels of intraspecific profile for all the studied gene of the ten athletes. Other enzymes including AvaI, Age and DraI were tested for their ability to differentiate these individuals.
\end{abstract}

Conclusion: The study demonstrated that the HGH gene contains useful genetic markers for the identification of athletes.

Key words: Polymorphisms, Athletes, PCR/RFLPs, HGH gene.

\section{Introduction}

Human growth hormone $(\mathrm{GH})$ affects a wide variety of physiological parameters such as growth performance, carcass composition, and milk production (Chung et al., 1983; Bauman et al., 1985 and Etherton et al., 1986). The genomic structure of the GH gene has been studied in different animals, including rat (Barta et al., 1981), bovine (Woychik et al., 1982), sheep (Byrne et al., 1987), pig (Vize and Wells 1987), human (Fiddes et al, 1979; Roskam et al., 1979 and DeNoto et al., 1981), goat (Kioka et al., 1989), chicken (Tanaka et al., 1992), and mice (Das et al., 1996). These animals share a similar gene structure containing five exons and four introns.

HGH is a polypeptide hormone suspected of being used by elite athletes to enhance sporting performance. Discovery of recombinant human $\mathrm{GH}$ (rhGH) in the possessions of Chinese swimmers bound for the 1998 World Swimming Championships and similar problems at the Tour de France cycling event in 1998 strongly suggest the abuse of $\mathrm{GH}$ at an elite level. This problem may affect the broader community, as shown by a report of GH use in high-school students in the U.S. (Rickert et al., 1992).

The rationale for the use of exogenous GH to enhance athletic performance is multifactorial. GH administration during childhood may augment adult height. GH's anabolic and lipolytic actions (Press, 1988) are demonstrated in studies in adults with GH deficiency, where modest doses of rhGH have been shown to increase lean body mass, skeletal muscle mass, proximal muscle force, and maximal and submaximal aerobic performance and to reduce fat mass (Cuneo et al., 1992). Other potentially beneficial effects of $\mathrm{GH}$ administration in adults with GH deficiency include increased cardiac output during exercise, increased sweating rates and improved thermal homeostasis, lipolysis to provide fuel for endurance sports, and possibly enhanced ligamentous strength and woundhealing rates. The side-effects of supraphysiological doses of rhGH include sodium and water retention (acute onset) and accelerated osteoarthritis, hypertension, cardiac failure, and an increased incidence of malignancies (delayed onset). Such concerns do not appear to deter abuse.

The International Olympic Committee and major sporting bodies ban administration of GH by athletes to enhance performance, but there is currently no approved means of detection. Measurement of serum or urinary total $\mathrm{GH}$ itself is unlikely to represent an optimal detection method because: 1) exogenous rhGH and endogenous $\mathrm{GH}$ have identical amino acid sequences, making chemical or immunological distinction difficult; 2) normal serum GH concentrations fluctuate widely, reflecting endogenous pulsatility and responses to stress and exercise (Cuneo 
and Wallace, 1994); 3) measurement of urinary $\mathrm{GH}$ is relatively insensitive as a marker of GH administration or acromegaly (Saugy et al., 1996 and Flanagan et al., 1997); and 4) chemical tagging of rhGH by pharmaceutical manufacturers would not solve the problem of unlicensed manufacture. Therefore, markers of $\mathrm{GH}$ action are being investigated as a potential test for $\mathrm{GH}$ abuse.

GH exerts major regulatory influences over several components of the $\mathrm{GH} / \mathrm{insulin}$ like growth factor (IGF) system. For example, GH modulates its own receptor expression and the circulating form of the extracellular component of the receptor, the high affinity GH-binding protein (GHBP) (Leung et al., 1987). GH exerts powerful stimulatory regulation over IGF-I, a protein produced in many tissues, where it exerts anabolic and mitogenic actions, and to a lesser extent over IGF-II. The IGFs are transported in serum bound to a number of IGF-binding proteins (IGFBPs), the predominant form comprising the ternary complex of IGF-I, IGFBP-3, and acid labile subunit (ALS) (Baxter, 1994). Responses of the GH/IGF system to rhGH administration are well described in GH-deficient adults (Rahkila, 1991), but data in normal adults and athletes are limited (Crist et al., 1988; Yarasheski et al., 1992; 1993 and Deyssig et al., 1993). The ratio of IGF-I/IGFBP-2 at rest has been proposed as a test for $\mathrm{GH}$ abuse (Kicman et al., 1997). Acute exercise, however, may also influence markers of GH action. For example, serum IGF-I (Bang et al., 1990; Cappon et al., 1994 and Schwarz et al., 1996) and IGFBP1 (Suikarri et al., 1989 and Koistinen et al., 1996) both increase transiently after acute exercise. In developing a GH detection system, the rate of disappearance of changes on markers of $\mathrm{GH}$ action must be described, but data in athletes either before or after exercise are unknown.

Height $(\mathrm{Ht})$ is determined by genetic, as well as environmental factors. The involvement of genetic factors in $\mathrm{Ht}$ is supported by several reports about the significant correlation between final $\mathrm{Ht}$ and parental Ht and about the growth of twins (Tanner et al., 1970; Smith, 1977; Martheny, 1990; Phillips and Matheny,
1990; Tsutomu et al., 1990 and Pai et al., 1994).

The effect of $\mathrm{GH}$ secretion on $\mathrm{Ht}$ during childhood is well established. Human with a deletion in the $G H-1$ gene are extremely short (Illig et al., 1971 and Phillips et al., 1981). Ht during childhood correlates with $\mathrm{GH}$ secretion determined by measurements of either GH levels integrated over $24 \mathrm{~h}$ or serum GH-dependent parameters, such as insulin-like growth factor (IGF) I and IGF binding protein-3 (Albertsson-Wikland and Rosberg, 1988 and Blum et al., 1993). Recently, in many endocrine disorders, polymorphisms of relevant human genes have been reported to be associated with polygenic disease. Examples of this includes the b-3 adrenergic receptor gene in noninsulindependent diabetes mellitus and obesity (Clement et al., 1995; Walston et al.; 1995 and Widen et al., 1995) and the Vitamin D receptor gene in osteoporosis (Morrison et al., 1994).

The present study attempted to identify polymorphisms in the $G H$ gene. Also, The aim of the study is to investigate the use of restriction map resulting from digestion of the HGH genes of athletes for diagnosis and selection at molecular level.

\section{Material and Methods}

Subjects: Ten healthy, adult athletes between the ages of 16 and 18 years were recruited for this study. DNA was extracted from whole blood using standard techniques (Higuchi 1989). Obtain 65-100 $\mu \mathrm{l}$ of blood with a heparinized tube. The blood expel immediately into a $1.5 \mathrm{ml}$ microfuge tube containing $20 \mu \mathrm{l}$ of $10 \mathrm{mM}$ EDTA. Mix immediately to prevent clot formation. Store on ice until processing. Add $200 \mu 1$ Lysis Buffer (0.32 M Sucrose; $10 \mathrm{mM}$ Tris- $\mathrm{HCl}$ (pH 7.5); $5 \mathrm{mM} \mathrm{MgCl2}$; $1 \% \mathrm{v} / \mathrm{v}$ Triton $\mathrm{X}-100)$ to each tube and vortex to suspend evenly. Microfuge 60 seconds at $5000 \mathrm{xg}$ to pellet nuclei. Remove and discard supernatant and repeat the steps two more times, or until no hemoglobin remains. Resuspend nuclear pellet in $100 \mu 1$ PBND (50 mM KCl; $10 \mathrm{mM}$ Tris- $\mathrm{HCl}(\mathrm{pH}$ 8.3); $2.5 \mathrm{mM} \mathrm{MgCl} 2 ; 0.1 \mathrm{mg} / \mathrm{ml}$ gelatin; $0.45 \%(\mathrm{v} / \mathrm{v})$ Nonidet P40 and $0.45 \%(\mathrm{v} / \mathrm{v})$ 
Tween 20) with $60 \mu \mathrm{g} / \mathrm{ml}$ proteinase $\mathrm{K}$ and incubate at $55{ }^{\circ} \mathrm{C}$ for 60 minutes (or overnight, if convenient). Heat samples to $97{ }^{\circ} \mathrm{C}$ for 10 minutes to inactivate proteinase $\mathrm{K}$. One $\mu \mathrm{l}$ of the resuspended pellet was checked by agarose gel electrophoresis for the presence of DNA, as in figure 1 .

\section{Polymerase Chain Reaction}

Amplification: To amplify the complete GH gene, one- $5 \mu$ l DNA of whole-cell DNA template was used plus oligonucleotide primers complementary either to the $5^{\prime}$ and 3 ends of the gene (1F1: 5'GAATTCAGGACTGAATCGTGC-3', and 1R2631: 5'-TCAACAGGCATCTACTGAGTGGA- 3'). The standard PCR reaction mixture was used (Kessing et al., 1989). The standard polymerase chain reaction program for amplification of $\mathrm{GH}$ gene was: $30-35$ cycles; one minute, $94^{\circ} \mathrm{C}$; two to three minutes, $45^{\circ} \mathrm{C}$; and three minutes, $72^{\circ} \mathrm{C}$. Deoxynucleotide triphosphates (dNTP; dATP, dGTP, dTTP, and dCTP) were from Perkin Elmer Cetus, USA. The taq DNA polymerase used for HG gene amplification was from Boehringer Mannheim Biochemica (Germany) and Gibco/BRL (Gaithersburg, Md., USA). One $\mu l$ of the PCR products was checked by gel electrophoresis for the presence of HG gene size ( 2650 bp), as in figure 2 .

$$
\text { Restriction fragment length }
$$

polymorphisms(RFLPs): RFLPs of the PCR products by the primers 1F1 and 1R2631, which covered the entire gene, were checked in 10 samples of the subjects. The enzymes used were AatI, AgeI, AvaI, AviII, BsaI, DraI, HindII, and SacI.

\section{Results}

DNA genome was extracted from ten training physical human between the ages of $16-18$ years (Fig. 1). The full-length Human Growth Hormone gene PCR products resulted in a product of approximately 2650 bp (Fig. 2).
AgeI, AvaI and DraI restriction endonucleases did not differentiate between the ten samples of the Human Growth Hormone gene. AgeI restriction enzyme digested the human Growth Hormone gene of the ten samples into two restriction fragments ( 100 and $\sim 2550$ bp; Fig. 3 and Table 1). AvaI restriction endonuclease cut the gene of the ten samples into four restriction bands $(\sim 300, \sim 320, \sim 660$ and $\sim 1370$ bp; Fig. 4 and Table 2). Also, DraI restriction enzyme fragmented the gene of the ten individuals into two fragments ( 150 and $\sim 2500$ bp; Fig. 5 Table 3).

AviII, BsaI, AatI, HindII and SacI restriction endonucleases clustered the ten individuals into two clusters with some differences. AviII restriction enzyme digested the gene of the samples (1-4 and 79) into three restriction fragments $(\sim 750$, $\sim 900$ and $\sim 1000 \mathrm{bp})$ and the samples $(5,6$ and 10) into four fragments $(\sim 200, \sim 550$, $\sim 900$ and $\sim 1000$ bp) (Fig. 6 and Table 4). $B s a$ I restriction endonuclease grouped the ten individuals into two groups when cut the gene samples (1-6 and 9) into six restriction bands $(\sim 150, \sim 200, \sim 250, \sim 350$, $\sim 650$ and $\sim 1050 \mathrm{bp}$ ) and did not digest the gene of samples 7, 8 and 10 (Fig. 7 and Table 5). AatI enzyme differentiated the ten individuals into two clusters when digested the gene of samples 1-5 and 9 into two restriction fragments ( $\sim 950$ and $\sim 1700 \mathrm{bp})$ and the samples 6-8 and 10 into three bands $(\sim 650, \sim 950$ and $\sim 1050 \mathrm{bp})$; Fig. 8 and Table 10. HindII restriction endonuclease grouped the individuals into two groups when digested the gene of samples 1-5 and 9 into two restriction bands $(\sim 450$ and $\sim 2200 \mathrm{bp}$ ) and the gene of samples 6-8 and 10 into four bands $(\sim 100, \sim 350, \sim 650$ and $\sim 1550$ bp); Fig. 9 and Table 7. Also, SacI restriction enzyme clustered the ten individuals into two clusters when the enzyme digested the gene of samples 1-6 into two bands ( 1050 and $\sim 1600 \mathrm{bp})$ and did not react with the gene of 7-10 samples (Fig. 10 and table 8). 
Table (1): The length of HGH genes fragments, resulted from digestion with AgeI enzyme in the investigated athletes. (see Fig. 3)

\begin{tabular}{|c|c|c|c|c|c|c|}
\hline & Band \#1 & Band \# 2 & Band \# 3 & Band \# 4 & Band \# 5 & Band \# 6 \\
\hline Sample \# 1 & $\sim 100$ & $\sim 2550$ & $\ldots \ldots \ldots$ & $\ldots \ldots \ldots$ & $\ldots \ldots \ldots \ldots$ & $\ldots \ldots+\ldots$ \\
\hline Sample \# 2 & $\sim 100$ & $\sim 2550$ & $\ldots \ldots \ldots$ & $\ldots \ldots \ldots$ & $\ldots \ldots \ldots$ & $\ldots \ldots \ldots$ \\
\hline Sample \# 3 & $\sim 100$ & $\sim 2550$ & $\ldots \ldots \ldots$ & $\ldots \ldots \ldots \ldots$ & $\ldots \ldots \ldots$ & $\ldots \ldots \ldots \ldots$ \\
\hline Sample \# 4 & $\sim 100$ & $\sim 2550$ & $\ldots \ldots \ldots \ldots$ & .......... & $\ldots \ldots \ldots$ & $\ldots \ldots \ldots$ \\
\hline Sample \# 5 & $\sim 100$ & $\sim 2550$ & $\ldots \ldots \ldots \ldots$ & $\ldots \ldots \ldots \ldots$ & $\ldots \ldots \ldots \ldots$ & $\ldots \ldots \ldots \ldots$ \\
\hline Sample \# 6 & $\sim 100$ & $\sim 2550$ & $\ldots \ldots \ldots \ldots$ & $\ldots \ldots \ldots$, & $\ldots \ldots \ldots \ldots$ & n....... \\
\hline Sample \# 7 & $\sim 100$ & $\sim 2550$ & $\ldots \ldots \ldots \ldots$ & $\ldots \ldots \ldots \ldots$ & $\ldots \ldots \ldots \ldots$ & .......... \\
\hline Sample \# 8 & $\sim 100$ & $\sim 2550$ & ......... & .......... & ......... & .......... \\
\hline Sample \# 9 & $\sim 100$ & $\sim 2550$ & $\ldots \ldots \ldots$ & $\ldots \ldots \ldots$ & $\ldots \ldots \ldots \ldots$ & $\ldots \ldots \ldots \ldots$ \\
\hline Sample \# 10 & $\sim 100$ & $\sim 2550$ & $\ldots \ldots \ldots \ldots$ & $\ldots \ldots \ldots \ldots$ & ......... & .......... \\
\hline
\end{tabular}

Table (2): The length of HGH genes fragments, resulted from digestion with AvaI enzyme in the investigated athletes. (see Fig. 4)

\begin{tabular}{|c|c|c|c|c|c|c|}
\hline & Band \#1 & Band \# 2 & Band \# 3 & Band \# 4 & Band \# 5 & Band \# 6 \\
\hline Sample \# 1 & $\sim 300$ & $\sim 320$ & $\sim 660$ & $\begin{array}{l}370 \\
\end{array}$ & $\ldots \ldots \ldots \ldots$ & $\ldots \ldots \ldots$ \\
\hline Sample \# 2 & $\sim 300$ & $\sim 320$ & $\sim 660$ & $\sim 1370$ & $\ldots$ & \\
\hline Sample \# 3 & $\sim 300$ & $\sim 320$ & $\sim 660$ & $\sim 1370$ & $\ldots \ldots \ldots \ldots$ & n........ \\
\hline Sample \# 4 & $\sim 300$ & $\sim 320$ & $\sim 660$ & $\sim 1370$ & $\ldots \ldots \ldots \ldots$ & .......... \\
\hline Sample \# 5 & $\sim 300$ & $\sim 320$ & $\sim 660$ & $\sim 1370$ & $\ldots \ldots \ldots \ldots$ & $\ldots$ \\
\hline Sample \# 6 & $\sim 300$ & $\sim 320$ & $\sim 660$ & $\sim 1370$ & $\ldots \ldots \ldots \ldots$ & $\ldots \ldots \ldots$ \\
\hline Sample \# 7 & $\sim 300$ & $\sim 320$ & $\sim 660$ & $\sim 1370$ & $\ldots \ldots \ldots \ldots$ & ......... \\
\hline Sample \# 8 & $\sim 300$ & $\sim 320$ & $\sim 660$ & $\sim 1370$ & $\ldots \ldots \ldots \ldots$ & ............ \\
\hline Sample \# 9 & $\sim 300$ & $\sim 320$ & $\sim 660$ & $\sim 1370$ & & \\
\hline Sample \# 10 & $\sim 300$ & $\sim 320$ & $\sim 660$ & $\sim 1370$ & .......... & .......... \\
\hline
\end{tabular}

Table (3): The length of HGH genes fragments, resulted from digestion with DraI enzyme in the investigated athletes. (see Fig. 5)

\begin{tabular}{|c|c|c|c|c|c|c|}
\hline & Band \#1 & Band \# 2 & Band \# 3 & Band \# 4 & Band \# 5 & Band \# 6 \\
\hline Sample \# 1 & $\sim 150$ & $\sim 2500$ & $\ldots \ldots \ldots \ldots$ & $\ldots \ldots \ldots \ldots$ & $\ldots \ldots \ldots \ldots$ & $\ldots \ldots \ldots \ldots$ \\
\hline Sample \# 2 & $\sim 150$ & $\begin{array}{l}2500 \\
\sim\end{array}$ & $\ldots \ldots \ldots \ldots$ & $\ldots \ldots \ldots \ldots$ & $\ldots \ldots \ldots \ldots$ & .......... \\
\hline Sample \# 3 & $\sim 150$ & $\sim 2500$ & $\ldots \ldots \ldots$ & $\ldots \ldots \ldots$ & $\ldots \ldots \ldots$ & $\ldots \ldots \ldots$ \\
\hline Sample \# 4 & $\sim 150$ & $\sim 2500$ & ......... & ......... & ......... & .......... \\
\hline Sample \# 5 & $\sim 150$ & $\sim 2500$ & $\ldots \ldots \ldots$ & $\ldots \ldots \ldots \ldots$ & $\ldots \ldots \ldots \ldots$ & $\ldots \ldots \ldots$ \\
\hline Sample \# 6 & $\sim 150$ & $\sim 2500$ & .......... & ......... & .......... & .......... \\
\hline Sample \# 7 & $\sim 150$ & $\sim 2500$ & $\ldots \ldots \ldots \ldots$ & $\ldots \ldots \ldots \ldots$ & $\ldots \ldots \ldots \ldots$ & $\ldots \ldots \ldots \ldots$ \\
\hline Sample \# 8 & $\sim 150$ & $\sim 2500$ & .......... & $\ldots \ldots \ldots \ldots$ & $\ldots \ldots \ldots \ldots$ & .......... \\
\hline Sample \# 9 & $\sim 150$ & $\sim 2500$ & $\ldots \ldots \ldots$ & $\ldots \ldots \ldots$ & $\ldots \ldots \ldots \ldots$ & .......... \\
\hline Sample \# 10 & $\sim 150$ & $\sim 2500$ & .......... & .......... & .......... & .......... \\
\hline
\end{tabular}

Table (4): The length of HGH genes fragments, resulted from digestion with AviII enzyme in the investigated athletes. (see Fig. 6)

\begin{tabular}{|c|c|c|c|c|c|c|}
\hline & Band \#1 & Band \# 2 & Band \# 3 & Band \# 4 & Band \# 5 & Band \# 6 \\
\hline Sample \# 1 & $\sim 750$ & $\sim 900$ & $\sim 1000$ & .......... & ......... & .......... \\
\hline Sample \# 2 & $\sim 750$ & $\sim 900$ & $\sim 1000$ & .......... & .......... & .......... \\
\hline Sample \# 3 & $\sim 750$ & $\sim 900$ & $\sim 1000$ & .......... & $\ldots \ldots \ldots$ & .......... \\
\hline Sample \# 4 & $\sim 750$ & $\sim 900$ & $\sim 1000$ & ......... & $\ldots$ & $\ldots$ \\
\hline Sample \# 5 & $\sim 200$ & $\sim 550$ & $\sim 900$ & $\sim 1000$ & .......... & .......... \\
\hline Sample \# 6 & $\sim 200$ & $\sim 550$ & $\sim 900$ & $\sim 1000$ & .......... & .......... \\
\hline Sample \# 7 & $\sim 750$ & $\sim 900$ & $\sim 1000$ & .......... & $\ldots \ldots \ldots$ & $\ldots \ldots \ldots$ \\
\hline Sample \# 8 & $\sim 750$ & $\sim 900$ & $\begin{array}{l}1000 \\
\end{array}$ & ......... & ......... & .......... \\
\hline Sample \# 9 & $\sim 750$ & $\sim 900$ & $\sim 1000$ & .......... & .......... & .......... \\
\hline Sample \# 10 & $\sim 200$ & $\sim 550$ & $\sim 900$ & $\sim 1000$ & $\ldots \ldots \ldots$ & $\ldots \ldots \ldots \ldots$ \\
\hline
\end{tabular}


Table (5): The length of HGH genes fragments, resulted from digestion with $B s a I$ enzyme in the investigated athletes. (see Fig. 7)

\begin{tabular}{|l|c|c|c|c|c|c|}
\hline & Band \#1 & Band \# 2 & Band \# 3 & Band \# 4 & Band \# 5 & Band \# 6 \\
\hline Sample \# 1 & $\sim 150$ & $\sim 200$ & $\sim 250$ & $\sim 350$ & $\sim 650$ & $\sim 1050$ \\
\hline Sample \# 2 & $\sim 150$ & $\sim 200$ & $\sim 250$ & $\sim 350$ & $\sim 650$ & $\sim 1050$ \\
\hline Sample \# 3 & $\sim 150$ & $\sim 200$ & $\sim 250$ & $\sim 350$ & $\sim 650$ & $\sim 1050$ \\
\hline Sample \# 4 & $\sim 150$ & $\sim 200$ & $\sim 250$ & $\sim 350$ & $\sim 650$ & $\sim 1050$ \\
\hline Sample \# 5 & $\sim 150$ & $\sim 200$ & $\sim 250$ & $\sim 350$ & $\sim 650$ & $\sim 1050$ \\
\hline Sample \# 6 & $\sim 150$ & $\sim 200$ & $\sim 250$ & $\sim 350$ & $\sim 650$ & $\sim 1050$ \\
\hline Sample \# 7 & $\sim 2650$ & $\ldots \ldots \ldots$ & $\ldots \ldots \ldots$ & $\ldots \ldots \ldots \ldots$ & $\ldots \ldots \ldots \ldots$ & $\ldots \ldots \ldots \ldots$ \\
\hline Sample \# 8 & $\sim 2650$ & $\ldots \ldots \ldots$ & $\ldots \ldots \ldots$ & $\ldots \ldots \ldots$ & $\ldots \ldots \ldots$ & $\ldots \ldots \ldots$ \\
\hline Sample \# 9 & $\sim 150$ & $\sim 200$ & $\sim 250$ & $\sim 350$ & $\sim 650$ & $\sim 1050$ \\
\hline Sample \# 10 & $\sim 2650$ & $\ldots \ldots \ldots \ldots$ & $\ldots \ldots \ldots$ & $\ldots \ldots \ldots \ldots$ & $\ldots \ldots \ldots \ldots$ & $\ldots \ldots \ldots \ldots$ \\
\hline
\end{tabular}

Table (6): The length of HGH genes fragments, resulted from digestion with AatI enzyme in the investigated athletes. (see Fig. 8)

\begin{tabular}{|c|c|c|c|c|c|c|}
\hline & Band \#1 & Band \# 2 & Band \# 3 & Band \# 4 & Band \# 5 & Band \# 6 \\
\hline Sample \# 1 & $\begin{array}{l}\sim 950 \\
\end{array}$ & $\sim 1700$ & ........... & ........... & ........... & ............. \\
\hline Sample \# 2 & $\sim 950$ & $\sim 1700$ & & & & \\
\hline Sample \# 3 & $\sim 950$ & $\sim 1700$ & & $\ldots \ldots$ & $\ldots$. & \\
\hline Sample \# 4 & $\sim 950$ & $\sim 1700$ & ............ & ............ & ............ & ............ \\
\hline Sample \# 5 & $\sim 950$ & $\sim 1700$ & & $\ldots$ & $\ldots$ & $\ldots$ \\
\hline Sample \# 6 & $\begin{array}{l}\sim 650 \\
\end{array}$ & $\sim 950$ & $\sim 1050$ & ........... & ........... & $\ldots \ldots \ldots$ \\
\hline Sample \# 7 & $\sim 650$ & $\sim 950$ & $\sim 1050$ & ............ & ........... & ............ \\
\hline Sample \# 8 & $\sim 650$ & $\sim 950$ & $\sim 1050$ & $\ldots$ & $\ldots$ & $\ldots$ \\
\hline Sample \# 9 & $\sim 950$ & $\sim 1700$ & & $\ldots \ldots \ldots \ldots$ & ............ & $\ldots \ldots$ \\
\hline Sample \# 10 & $\sim 650$ & $\sim 950$ & $\sim 1050$ & ............ & $\ldots \ldots \ldots$ & $\ldots \ldots \ldots$ \\
\hline
\end{tabular}

Table (7): The length of HGHgenes fragments, resulted from digestion with HindII enzyme in the investigated athletes. (see Fig. 9)

\begin{tabular}{|c|c|c|c|c|c|c|}
\hline & Band \#1 & Band \# 2 & Band \# 3 & Band \# 4 & Band \# 5 & Band \# 6 \\
\hline Sample \# 1 & $\sim 450$ & $\sim 2200$ & & & & \\
\hline Sample \# 2 & $\sim 450$ & $\sim 2200$ & ............ & $\ldots \ldots \ldots$ & $\ldots \ldots \ldots$ & .......... \\
\hline Sample \# 3 & $\sim 450$ & $\begin{array}{l}2200 \\
\end{array}$ & ............ & ........... & ............ & ............ \\
\hline Sample \# 4 & $\sim 450$ & $\sim 2200$ & $\ldots$ & $\ldots$ & ........... & $\ldots$ \\
\hline Sample \# 5 & $\sim 450$ & $\sim 2200$ & ............ & ........... & ........... & ............ \\
\hline Sample \# 6 & $\sim 100$ & $\sim 350$ & $\sim 650$ & $\sim 1550$ & $\ldots$ & …....... \\
\hline Sample \# 7 & $\sim 100$ & $\sim 350$ & $\sim 650$ & $\sim 1550$ & ........... & ........... \\
\hline Sample \# 8 & $\sim 100$ & $\sim 350$ & $\sim 650$ & $\sim 1550$ & $\ldots$ & \\
\hline Sample \# 9 & $\sim 450$ & $\begin{array}{l}2200 \\
\end{array}$ & & & $\ldots \ldots \ldots$ & $\ldots \ldots \ldots$ \\
\hline Sample \# 10 & $\sim 100$ & $\sim 350$ & $\sim 650$ & $\sim 1550$ & ............ & …… \\
\hline
\end{tabular}

Table (8): The length of HGHgenes fragments, resulted from digestion with SacI enzyme in the investigated athletes. (see Fig. 10)

\begin{tabular}{|c|c|c|c|c|c|c|}
\hline & Band \#1 & Band \# 2 & Band \# 3 & Band \# 4 & Band \# 5 & Band \# 6 \\
\hline Sample \# 1 & $\sim 1050$ & $\sim 1600$ & & & & \\
\hline Sample \# 2 & $\sim 1050$ & $2 \sim 1600$ & n......... & $\ldots \ldots \ldots$ & $\ldots \ldots \ldots$ & ........... \\
\hline Sample \# 3 & $\sim 1050$ & \begin{tabular}{|l|}
$\sim 1600$ \\
\end{tabular} & $\ldots \ldots \ldots$ & ........... & ........... & $\ldots \ldots \ldots \ldots$ \\
\hline Sample \# 4 & $\sim 1050$ & $\sim 1600$ & $\ldots$ & $\ldots$ & $\ldots$. & $\ldots$ \\
\hline Sample \# 5 & $\sim 1050$ & \begin{tabular}{|l|}
$\sim 1600$ \\
\end{tabular} & ............ & ........... & ........... & $\ldots \ldots \ldots$ \\
\hline Sample \# 6 & $\sim 1050$ & $\sim 1600$ & $\ldots$ & $\ldots$ & $\ldots$ & $\ldots$ \\
\hline Sample \# 7 & $\sim 2650$ & ............ & ............ & $\ldots \ldots \ldots \ldots$ & $\ldots \ldots \ldots$ & ............ \\
\hline Sample \# 8 & 22650 & \begin{tabular}{|l|}
$\ldots \ldots \ldots \ldots$ \\
\end{tabular} & $\ldots \ldots \ldots \ldots$ & f.......... & f......... & f.......... \\
\hline Sample \# 9 & $\sim 2650$ & \begin{tabular}{|l|}
$\ldots \ldots \ldots \ldots$ \\
\end{tabular} & $\ldots \ldots \ldots \ldots$ & …....... & ............ & ........... \\
\hline Sample \# 10 & $\sim 2650$ & ............ & ............ & . . & $\ldots \ldots \ldots$ & ……… \\
\hline
\end{tabular}




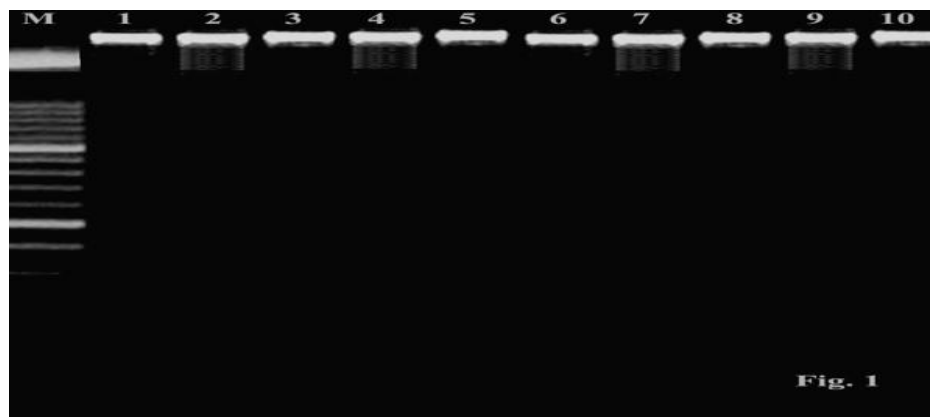

Figure 1: Total DNA genome from ten athletes.

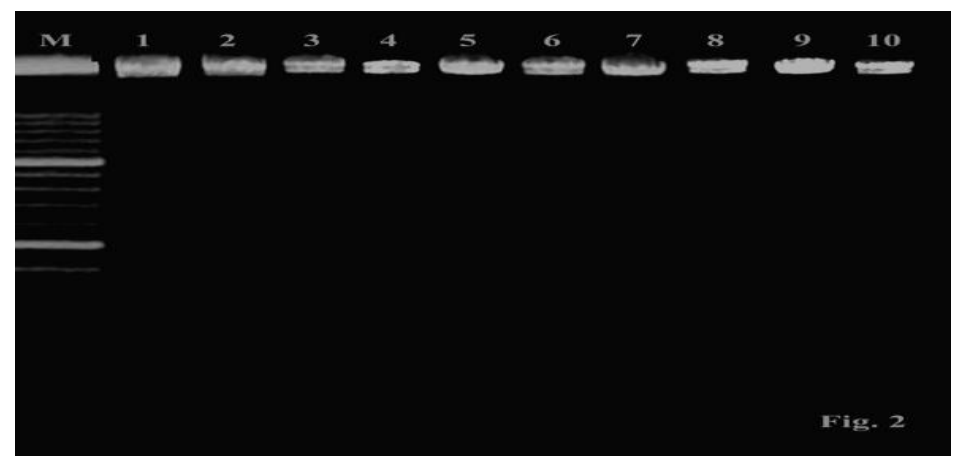

Figure 2: Full-length of HGH gene of the ten athletes.

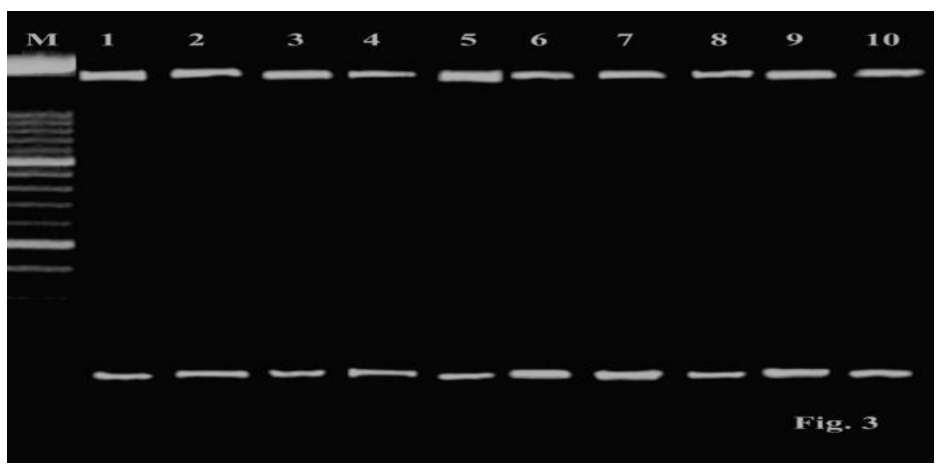

Figure 3: The length of HGH genes fragments, resulted from digestion with AgeI enzyme in the investigated athletes.

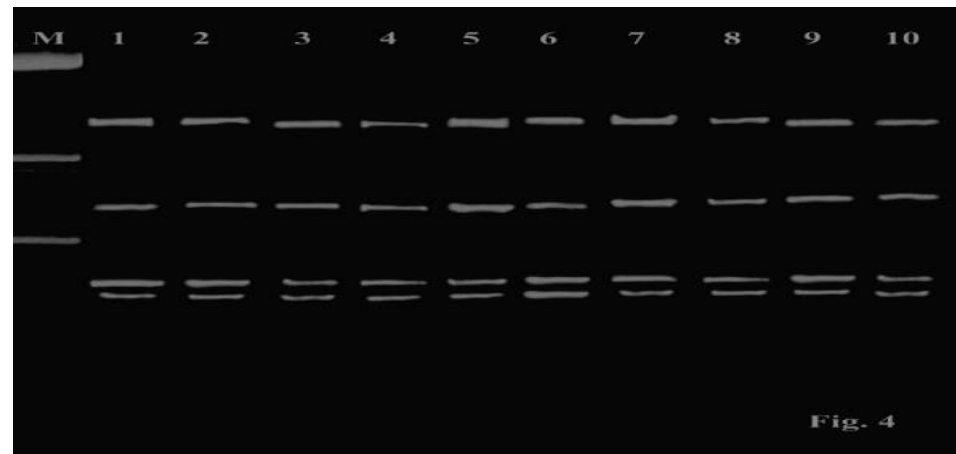

Figure 4: The length of HGH genes fragments, resulted from digestion with AvaI enzyme in the investigated athletes. 


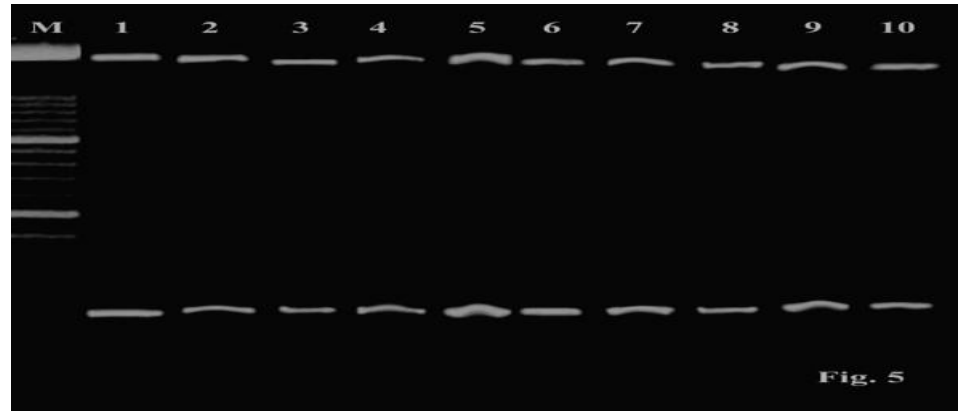

Figure 5: The length of HGH genes fragments, resulted from digestion with DraI enzyme in the investigated athletes.

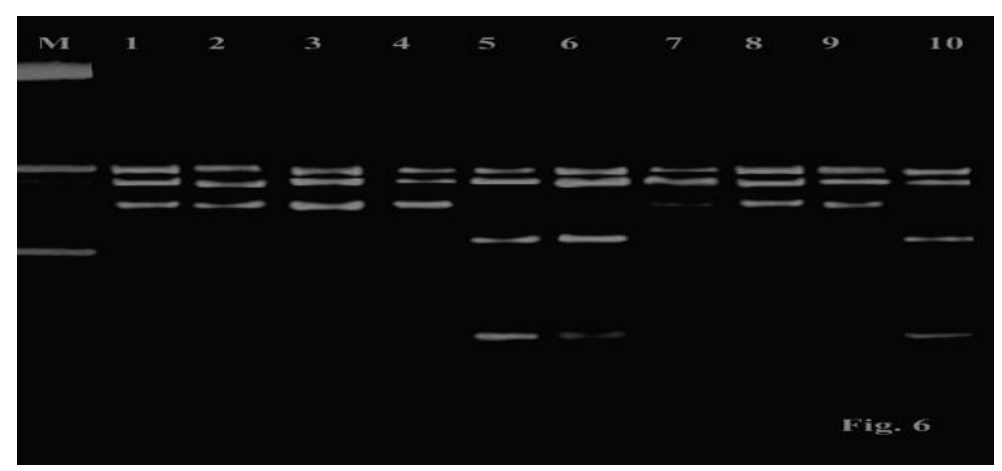

Figure 6: The length of HGH genes fragments, resulted from digestion with AviII enzyme in the investigated athletes.

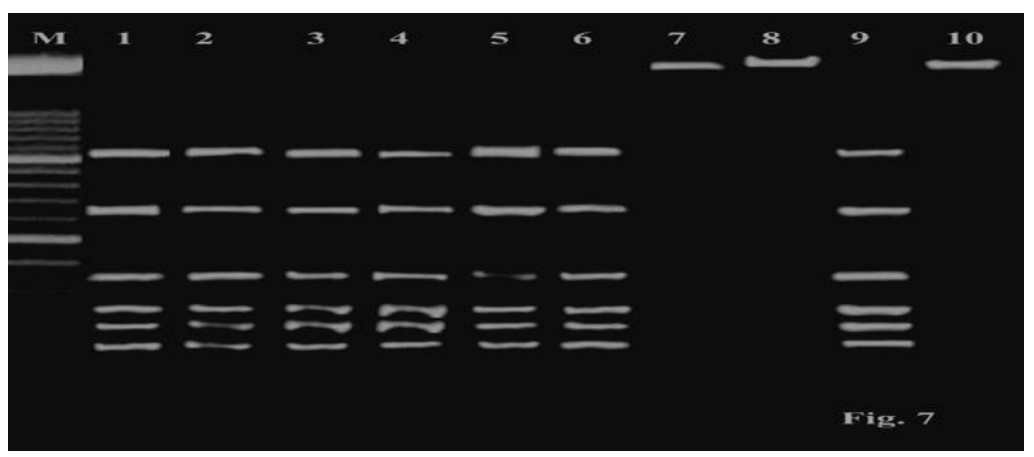

Figure 7: The length of HGH genes fragments, resulted from digestion with BsaI enzyme in the investigated athletes.

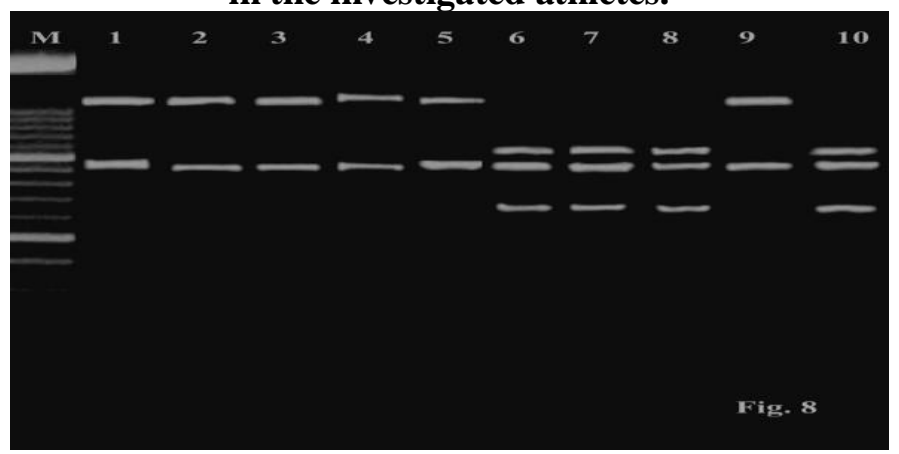

Figure 8: The length of HGH genes fragments, resulted from digestion with AatI enzyme in the investigated athletes. 


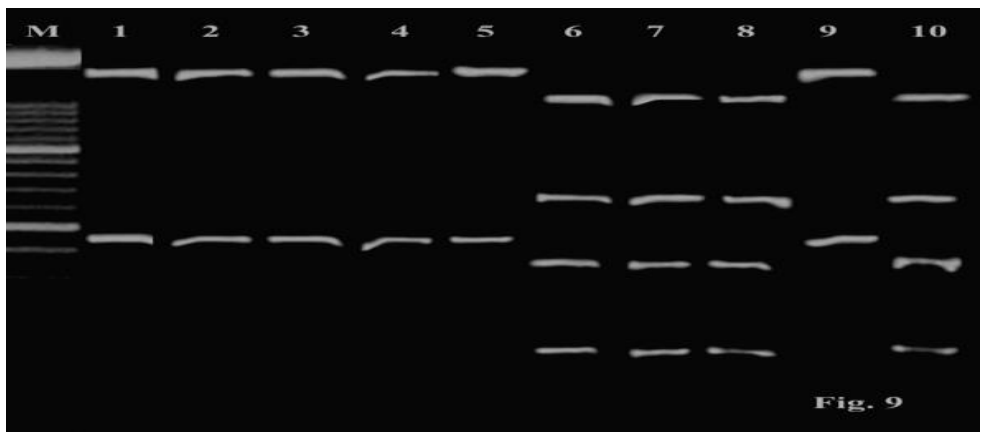

Figure 9: The length of HGH genes fragments, resulted from digestion with HindII enzyme in the investigated athletes.

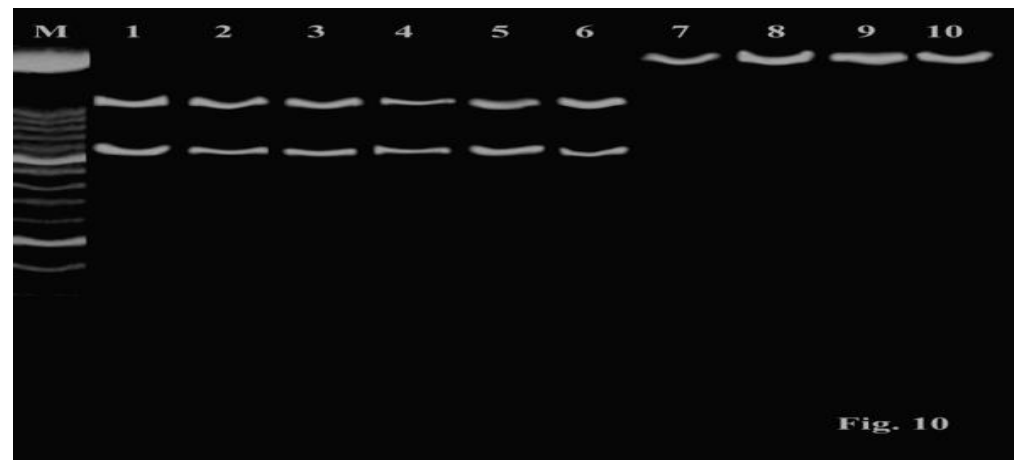

Figure 10: The length of HGH genes fragments, resulted from digestion with SacI enzyme in the investigated athletes.

\section{Discussion}

In recent years, DNA polymorphisms have been widely studied in the GH gene of various animals (Stephen et al., 2001). Some polymorphisms in the $G H$ gene were identified in this study, which may explain part of the genetic determination of GH at the molecular level. Polymorphisms in the GH gene may also be associated with idiopathic GH deficiency. The molecular mechanism of variation in $\mathrm{GH}$ has not yet been fully analyzed. Although more than 10 polymorphic sites of the $G H$ gene were reported (DeNote et al., 1981, Chen et al., 1989, Giordano et al., 1997 and Wagner et al., 1997).

A point mutation of the coding or noncoding $G H$ gene was reported to cause the absence or decrease in GH secretion (Duquesnoy et al., 1990; Cogan et al., 1993; Binder et al., 1996; Cogan et al., 1996 and Missarelli et al., 1997), which allows for the hypothesis that the polymorphisms of the $G H$ gene may be considered as part of the continuous spectrum of mutations in this gene. The study of the molecular mechanisms of this phenomenon would be worth pursuing.

The PCR/RFLP analysis of the HG gene has proven to be effective in diagnosis and selection studies of athletes to refute the classical identification and to estimate genetic similarities and differences among them. The molecular data emerged as a useful tool for studying athletes with great phenotypic plasticity (Oriola et al., 1991 and Parry et al., 1991 and Hasegawa et al., 2006).

With these genotypically defined groups as a basis, a PCR-linked restriction fragment length polymorphism (RFLP) was devised for rapid identification of the ideal athletic individuals. The research results indicated that the first four specimens of the ten athletic individuals are polyphylogenic 
when compared to the rest of the ten individuals. Also, the results proved that the first four individuals were the most suitable for athletic selection.

Inexpensive way to resolve this dilemma was to use an existing method of studying relationships among the ten athletes in which phylogeny is reconstructed on the basis of $\mathrm{HGH}$ gene RFLPs. RFLPs are dissimilarities in electrophoretic profile patterns. The contribution was to find the sites in the $\mathrm{HGH}$ genes where some restriction endonucleases act. Many investigators (Rivera et al., 1998; Wolfforth et al., 2000; Nakamura et al, 2002 and Shneider et al., 2004) have used restriction fragment length polymorphisms (RFLPs) of some genes as a basis for examining relationships among fitness, height and weigh of the athletes. Using restriction enzyme analysis of the $\mathrm{HGH}$ gene as an experimental tool to examine athletes proved to be suitable to find specific enzymes for selection of individuals.

\section{References}

1. Albertsson-Wikland $\mathbf{K}$ and Rosberg $\mathbf{S}$ (1988): Analysis of 24-hour growth hormone profiles in children: relation to growth. J. Clin. Endocrinol. Metab., 67:493-500.

2. Bang P, Brandt J, Degerblad M, Enberg G, Kaijser L, Thoren $M$ and Hall $K$ (1990): Exercise-induced changes in insulin-like growth factors and their low molecular weight binding protein in healthy subjects and patients with growth hormone deficiency. Eur. J. Clin. Invest., 20:285292.

3. Barta A, Richards RI, Baxter JD and Shine J (1981): Primary structure and evolution of rat growth hormone gene. Proc. Natl. Acad. Sci. US., 78:4867-4871.

4. Bauman DE, Eppard PJ, Degeeter MJ and Lanza GM (1985): Responses of highproducing dairy cows to long-term treatment with pituitary somatotropin and recombinant somatotropin. J. Dairy Sci., 68:1352-1362.

5. Baxter RC (1994): Insulin-like growth factor binding proteins in the human circulation: a review. Horm. Res., 42:140 144.

6. Binder G, Brown $M$ and Parks JS (1996): Mechanisms responsible for dominant expression of human growth hormone gene mutations. J. Clin. Endocrinol. Metab., 81:4047-4050.

7. Blum WF, Albertsson-Wikland $\mathbf{K}$, Rosberg S and Ranke MB (1993): Serum levels of IGF-I and IGF binding protein 3 reflect spontaneous growth hormone secretion. J. Clin. Endocrinol. Metab., 76:1610-1616.

8. Byrne CR, Wilson BW and Ward KA (1987): The isolation and characterization of the ovine growth hormone gene. Aust. J. Biol. Sci., 40:459-468.

9. Cappon J, Brasel JA, Mohan S and Cooper DM (1994): Effect of brief exercise on circulating insulin-like growth factor I. J. Clin. Endocrinol. Metab., 76:2490 -2496.

10. Chen EY, Liao YC, Smith DH, BarreraSaldana HA, Gelina RE and Seeburg PH (1989): The human growth hormone locus: nucleotide sequence, biology, and evolution. Genomics., 4:479-497.

11. Chung CS, Etherton TD and Wiggins JP (1983): Stimulation of swine growth by porcine growth hormone. J. Anim. Sci., 60:118-130.

12. Clement K, Vaisse C, Manning BSJ, Basdevant A, Guy-Grand B, Ruiz J, Silver KD, Shuldiner AR, Froguel $P$ and Strosberg D (1995): Genetic variation in the B3-adrenergic receptor and an increased capacity to gain weight in patients with morbid obesity. N. Engl. J. Med., 333:352354.

13. Cogan JC, Phillips III JA, Sakati N, Firisch H, Schober $E$ and Milner RD (1993): Heterogeneous growth hormone (GH) gene mutations in familial $\mathrm{GH}$ deficiency. J. Clin. Endocrinol. Metab., 76:1224-1228.

14. Cogan JD, Ramel B, Lehto M, Phillips J $3^{\text {rd }}$, Prince M, Blizzard RM, de Ravel TJ, Brammert $M$ and Groop $L$ (1996): Recurring dominant negative mutation causes autosomal dominant growth hormone deficiency-a clinical research center study. J. Clin. Endocrinol. Metab., 80:3591-3595.

15. Crist DM, Peake GT, Egan PA and Waters DL (1988): Body composition response to exogenous $\mathrm{GH}$ during training in highly conditioned adults. J. Appl. Physiol., 65:579-584.

16. Cuneo RC, Salomon F, McGauley GA and So"nksen PH (1992): The growth hormone deficiency syndrome in adults. Clin. Endocrinol. (Oxf)., 37:387- 397.

17. Cuneo RC and Wallace JD (1994): Growth hormone, insulin-like growth 
factors and sport. Endocrinol. Metab., 1:313.

18. Das P, Meyer L, Seyfert HM, Brockmann G and Schwerin M (1996): Structure of the growth hormone-encoding gene and its promoter in mice. Gene, 169:209-213.

19. DeNote FM, Moore DD and Goodman HM (1981): Human growth hormone DNA sequence and mRNA structure: possible alternative splicing. Nucleic Acids Res., 9:3719-3730.

20. Deyssig R, Frisch H, Blum WF and Waldhor $T$ (1993): Effect of growth hormone treatment on hormonal parameters, body composition and strength in athletes. Acta Endocrinol. (Copenh)., 128:313-318.

21. Duquesnoy $P$, Amselem $S$, Gourmelen $M$, Le Bouc $Y$ and Goossens $M$ (1990): A frameshift mutation causing isolated growth hormone deficiency type IA (Abstract)., Am. Soc. Hum. Genet., 76:A110 (abstract).

22. Etherton TD, Wiggins JP, Cung CS and Walton PE (1986): Stimulation of pig growth performance by porcine growth hormone and growth hormone releasing factor. J. Anim. Sci., 6:1389-1399.

23. Fiddes JC, Seeburg PH, DeNoto FM, Hallewell RA, Baxter JD and Goodman HM (1979): Structure of genes for human growth hormone and chorionic somatomammotropin. Proc. Natl. Acad. Sci. US., 76:4294- 298.

24. Flanagan DEH, Taylor MC, Parfitt V, Mardell R, Wood PJ and Leatherdale BA (1997): Urinary growth hormone following exercise to assess growth hormone production in adults. Clin. Endocrinol. (Oxf)., 46:425-429.

25. Giordano M, Marchetti C, Chiorboli E, Bona $G$ and Richiardi PM (1997): Evidence for gene conversion in the generation of extensive polymorphism in the promoter of the growth hormone gene. Hum. Genet., 100:249 -255.

26. Hasegawa Y, Fujii K, Yamada M, Igarashi Y, Tachibana K, Tanaka T, Onigata $K$, Nishi $Y$, Kato $S$ and Hasegawa $T$ (2006): Identification of Novel Human GH-1 Gene Polymorphisms that Are Associated with Growth Hormone Secretion and Height J. Clin. Endocrinol.Metab., 85(3): 1290- 1295.

27. Illig A, Prader A, Ferrandez $M$ and Zachmann M (1971): Hereditary prenatal growth hormone deficiency with increased tendency to growth hormone antibody formation, A-type of isolated growth hormone deficiency. Acta Pediat. Scand. (Suppl)., 60:607-610.

28. Kicman AT, Miell JP, Teale JD, Powrie J, Wood PJ, Laidler P, Milligan PJ and Cowan DA (1997): Serum IGF-I and IGF binding proteins 2 and 3 as potential markers of doping with human GH. Clin. Endocrinol. (Oxf)., 47:43-50.

29. Kioka N, Manabe E, Abe M, Hashi H, Yato M, Okuno M, Yamano Y, Sakai H, Komano T, Utsumi $K$ and Iritani $A$ (1989): Cloning and sequencing of goat growth hormone gene. Agric. Biol. Chem., 53:1583-1587.

30. Koistinen H, Koistinen R, Selenius L, Ylikorkala Q and Seppala M (1996): Effect of marathon run on serum IGF-I and IGF-binding protein 1 and 3 levels. J. Appl. Physiol., 80:760 -764.

31. Leung DW, Spencer SA, Cachianes G, Hammonds RG, Collins C, Henzel WJ, Barnard R, Waters MJ and Wood WI (1987): Growth hormone receptor and serum binding protein: purification, cloning and expression. Nature., 330:537-543.

32. Martheny Jr AP (1990): Developmental behavior genetics: contributions for the Louisville Twin Study. In: Hahn ME, Hewitt JK, Henderson ND, Benno RH, eds. Developmental behavior genetics: neutral biometrical, and evolutionary approaches. New York: Oxford University Press, 2539.

33. Missarelli C, Herrera L, Mericq V and Carvallo P (1997): Two different 59 splice site mutations in the growth hormone gene causing autosomal dominant growth hormone deficiency. Hum. Genet., 101:113-117.

34. Morrison NA, Qi JC, Tokita A, Kelly PJ, Crofts L, Nguyen TV, Sambrook PN and Eisman JA (1994): Prediction of bone density from vitamin D receptor alleles. Nature., 367:284 -287.

35. Nakamura O, Ishii T, Ando Y, Amagai H, Oto M, Imafuji $T$ and Tokuyama $K$ (2002): Potential role of vitamin D receptor gene polymorphism in determining bone phenotype in young male athletes. J. Appl. Physiol., 93(6):1973-9.

36. Oriola J Casamitjana $\mathbf{R}$, Nogues $\mathbf{N}$, Pages R, Romerol $M$ and Rivera-Fillat $F$ (1991): Rsal polymorphism of the human growth hormone gene (GH1). Nucleic Acids Research, 19(24): 6983.

37. Pai CK, Matheny Jr AP and Lang CA (1994): Insulin-like growth factor-I comparisons in healthy twin children. J. Clin. Endocrinol. Metab., 78:310 - 312. 
38. Parry PJ, Markiel D, Fearon ER, Nigro JM, Vogelstein $B$ and Bodmer WF (1991): PCR-based detection of two MspI polymorphic sites at D18S8. Nucleic Acids Research, 19(24): 6983.

39. Phillips III JA, Hjelle BL, Seeburg PH and Zachmann M (1981): Molecular basis for familial isolated growth hormone deficiency. Proc. Natl. Acad. Sci. US., 78:6372-6375.

40. Phillips K and Matheny Jr AP (1990): Quantitative genetic analysis of longitudinal trends in height: preliminary results form the Louisville Twin study. Acta Genet. Med. Gemellol., 39:143-163.

41. Press M (1988): Growth hormone and metabolism. Diabetes Metab Rev., 4:391414.

42. Rahkila PJ (1991): Human growth hormone replacement therapy: pharmacological and clinical aspects. Endocr. Rev., 12:189 -207.

43. Rickert VI, Pawlak Morello C, Sheppard V and Jay MS (1992): Human growth hormone: a new substance of abuse among adolescents? Clin. Pediatr., 31:723-726.

44. Rivera MA, Wolfarth B, Dionne FT, Chagnon M, Simoneau JA, Boulay MR, Song TM, Perusse L, Gagnon J, Leon AS, Rao DC, Skinner JS, Wilmore JH, Keul J and Bouchard C (1998): Three mitochondrial DNA restriction polymorphisms in elite endurance athletes and sedentary controls. Med. Sci. Sports Exerc., 30(5):687-90.

45. Roskam WG and Rougeon F (1979): Molecular cloning and nucleotide sequence of the human growth hormone structural gene. Nucleic Acids Res., 7:305-320.

46. Saugy M, Cardis C, Schweizer C, Veuthey J, Rivier $L$ and Veuthey JL (1996): Detection of human growth hormone doping in urine: out of competition tests are necessary. J. Chromatogr. B. Biomed. Appl., 687:201211.

47. Schwarz AJ, Brasel JA, Hintz RL, Mohan S and Cooper DM (1996): Acute effect of brief low- and high-intensity exercise on circulating insulin-like growth factor (IGF) I II and IGF-binding protein-3 and its proteolysis in young healthy men. $\mathrm{J}$. Clin. Endocrinol. Metab., 81:3492-3497.

48. Shneider OV, Obrezan AG, Makeeva ED, Stupnitskii AA, Spivak IM and Mikhelson VM (2004): Impact of angiotensin-converting enzyme, angiotensinogen, endothelial NO synthase, and bradykinin receptor B2 gene polymorphisms on myocardium in patients with hypertension and in athletes. Tsitologiia., 46(1):69-78.

49. Smith DW (1977): Basics and nature of growth. In: Smith DW ed. Growth and its disorders., 1-17.

50. Stephen CY, Xiquan Zhang IP and Frederick CL (2001): Genomic Growth Hormone Gene Polymorphisms in Native Chinese Chickens. Soc. Exp. Biol. Med., 458-462.

51. Suikarri A-M, Sane T, Seppala M, YkiJarvinen H, Karonen S-L and Koivisto VA (1989): Prolonged exercise increases serum insulin-like growth factor-binding protein concentrations. J. Clin. Endocrinol. Metab., 68:141-144.

52. Tanaka M, Hosokawa Y, Watahiki M and Nakashima K (1992): Structure of the chicken growth hormone-encoding gene and its promoter region. Gene., 112:235239.

53. Tanner JM, Goldstein $H$ and Whitehouse RH (1970): Standards for children's height at ages 2-9 years allowing for height of parents. Arch. Dis. Child., 45:755-762.

54. Tsutomu O, Nobutake M, Shinya $\mathbf{T}$ and Mitsuru O (1990): Target height and target range for the Japanese. Jpn. J. Pediatr. (in Japanese)., 94:1535-1540.

55. Vize PD and Wells JRE (1987): Isolation and characterization of the porcine growth hormone gene. Gene., 55:339-344.

56. Wagner JK, Eble A, Cogan JD, Prince MA, Phillips JA and Mullis PE (1997): Allelic variations on the human growth hormone-1 gene promoter of growth hormone- deficient patients and normal controls., Eur. J. End., 137:474-481.

57. Walston J, Silver K, Bogardus C, Knowler WC, Celi FS, Austin S, Manning B, Strosberg AD, Stern MP and Raben N (1995): Time of onset of noninsulindependent diabetes mellitus and genetic variation in the B3-adrenergicreceptor gene. N. Engl. J. Med., 333:343347.

58. Widen E, Lehto M, Kanninen T, Walston J, Shuldiner AR and Groop LC (1995): Association of a polymorphism in the B3adrenergic-receptor gene with features of the insulin resistance syndrome in Finns. N. Engl. J. Med., 333:348 -351.

59. Wolfarth B, Rivera MA, Oppert JM, Boulay MR, Dionne FT, Chagnon M, Gagnon J, Chagnon Y, Perusse L, Keul J and Bouchard C (2000): A polymorphism in the alpha2a-adrenoceptor gene and endurance athlete status. Med. Sci. Sports Exerc., 32(10):1709-12. 
60. Woychik RP, Camper SA, Lyons RH, Horowitz S, Goodwin EC and Rottoman FM (1982): Cloning and nucleotide sequencing of the bovine growth hormone gene. Nucleic Acids Res., 10:7192-7210.

61. Yarasheski KE, Campbell JA, Smith K, Rennie MJ, Holloszy JO and Bier DM (1992): Effect of growth hormone and resistance exercise on muscle growth in young men. Am. J. Physiol. Endocrinol. Metab., 262:E261-E267.

62. Yarasheski KE, Zachwieja JJ, Angelopoulos TJ and Bier DM (1993): Short-term growth hormone treatment does not increase muscle protein synthesis in experienced weight lifters. J. Appl. Physiol., 74:3073-3076. 


\section{التعرف على تعدد أشكال جين هرمون النمو البشرى للرياضيين

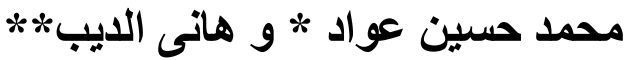

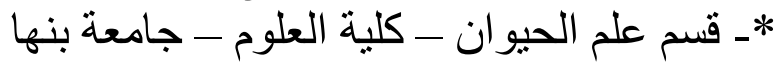 \\ ** * قسم التدريب الرياضى ـ كلية التربية الرياضية - جامعة المنوفية}

أصبحت منطلبـات عمليـات التدريب الرياضـي وتطوير القدر ات الوظيفيـة في الآونـة الأخيرة

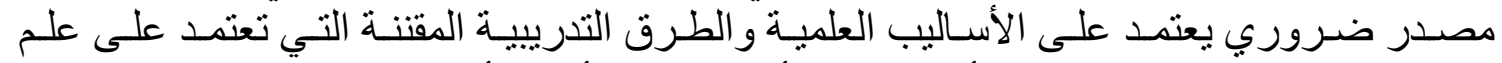

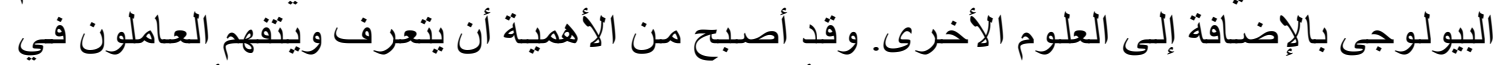

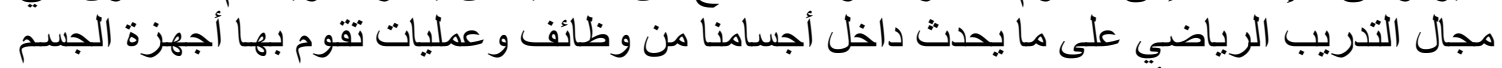

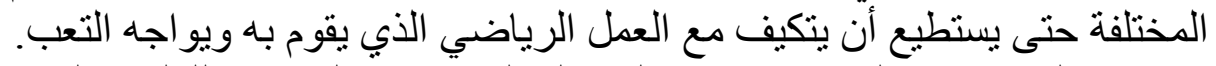

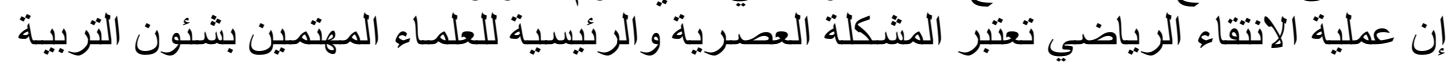

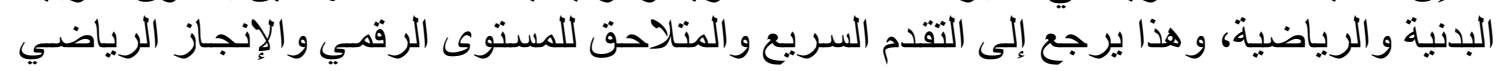

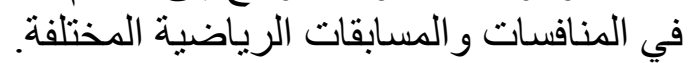

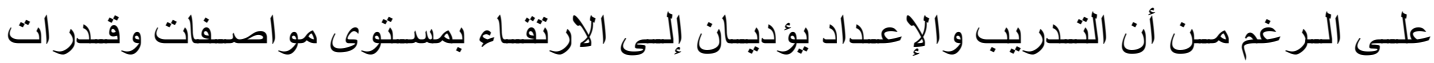

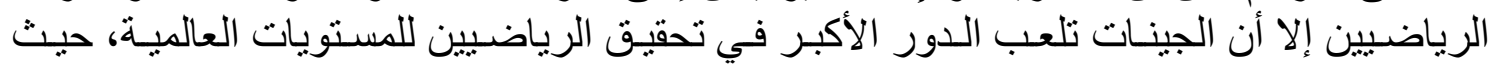

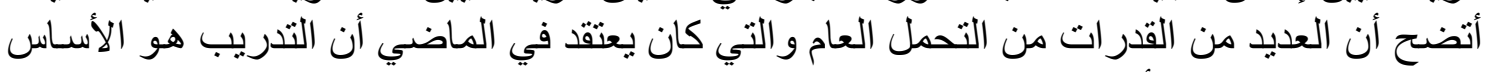

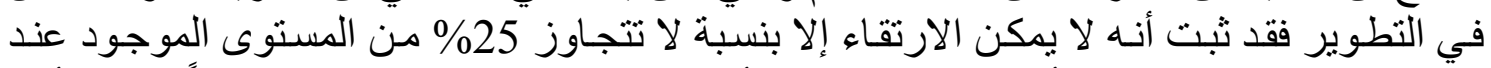

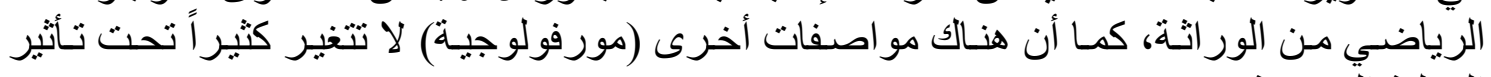
العملية التدريبية.

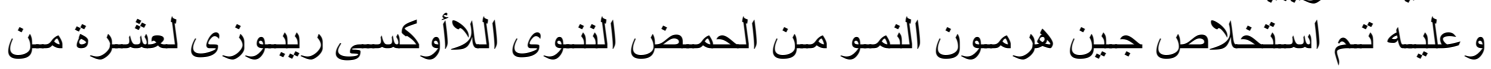

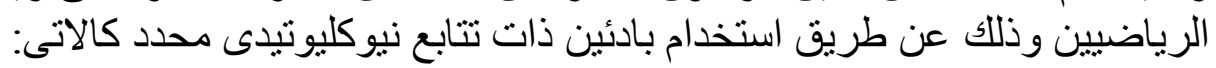
1F1: 5'-GAATTCAGGACTGAATCGTGC-3'

1R2631: 5'-TCAACAGGCATCTACTGAGTGGA- 3'

و استخدمت فى هذه الدر اسـة ثمانيـة أنواع مـن إنزيمـات القصر لهضم جين هرمون النمو للاعبين

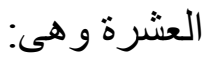
AatI, AgeI, AvaI, AviII, BsaI, DraI, HindII, and SacI وذللك للحصول على أطو ال القطع المحددة والمتغايرة لجين هرمون النمو موضع الدر اسة. وكانت أبرز النتائج كالتالى:

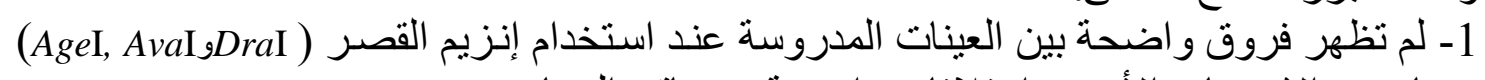

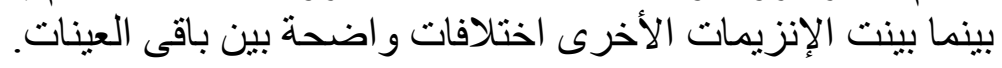

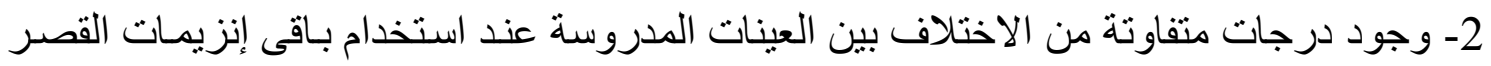
(AatI, BsaI AvilI, HindII Sacl)

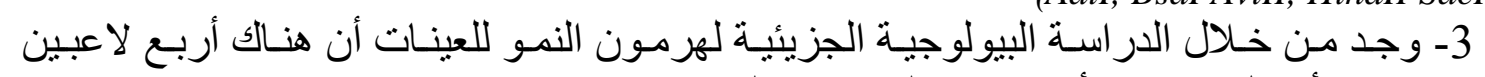

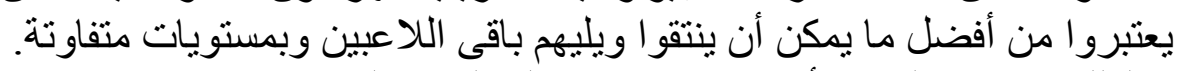

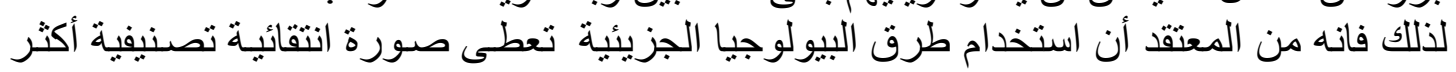

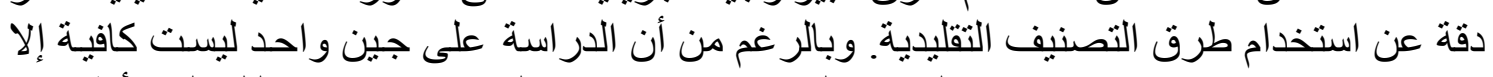

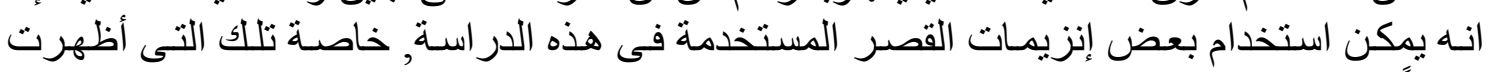
فروقاً بين العينات, كمجسات للتعرف والتزيدات التمبيز و الانتقاء للاعبين. 